\title{
Composting Constraints and Prospects in Bangladesh: A Review
}

\author{
Mst Marufa Sultana1, Mohammad Golam Kibria², M. Jahiruddin², Md. Anwarul Abedin²* \\ ${ }^{1}$ Soil Science Division, Bangladesh Agricultural Research Institute, Gazipur, Bangladesh \\ ${ }^{2}$ Department of Soil Science, Bangladesh Agricultural University, Mymensingh, Bangladesh \\ Email: *m.a.abedin@bau.edu.bd
}

How to cite this paper: Sultana, M. M., Kibria, M. G., Jahiruddin, M., \& Abedin, Md. A. (2020). Composting Constraints and Prospects in Bangladesh: A Review. Journal of Geoscience and Environment Protection, $8,126-139$.

https://doi.org/10.4236/gep.2020.89008

Received: August 11, 2020

Accepted: September 21, 2020

Published: September 24, 2020

Copyright $\odot 2020$ by author(s) and Scientific Research Publishing Inc. This work is licensed under the Creative Commons Attribution International License (CC BY 4.0).

http://creativecommons.org/licenses/by/4.0/

\begin{abstract}
Composting is a suitable environment-friendly technique to modify organic waste to organic fertilizers and works as soil conditioners by regulating different biological processes. The main objective of a sustainable agricultural production system can be achieved by using quality compost and thereby improving soil health and increased crop yield. This desktop research summarizes the role of composting for sustainable agricultural development with their prospective role, opportunities, and challenges in the context of Bangladesh. Some attention is also given to the composting process and compost industries in Bangladesh. Benefits and constraints regarding the use of compost for achieving sustainable agricultural production systems are also discussed.
\end{abstract}

\section{Keywords}

Composting, Sustainable Agriculture, Bangladesh

\section{Introduction}

Compost is the final product of aerobic decomposition of organic matter (Senesi, 1989). It is commonly considered as a soil conditioner and widely used as balanced fertilizer in the agricultural crop field (Lal, 2008). Compost is generally not rich in all essential plant nutrients (Eghball, Power, Gilley, \& Doran, 1997), and the crop does not receive an immediate response to organic fertilization (Noyd, Pfleger, \& Norland, 1996). That is why poor farmers in Bangladesh are not interested in using compost in their crop field, and they mostly rely on chemical fertilizers for higher crop yield without or less use of organic fertilizers such as compost (Martínez-Blanco et al., 2013). This excessive use of chemical fertilizers 
leads to deterioration of soil fertility status and soil health due to low organic matter content of the soil. Most of the soils of Bangladesh have low organic matter content, usually less than $2 \%$ (Bhuiya, 1987). About $45 \%$ of the net cultivable area of the country has less than $1 \%$ organic matter content (BARC, 1999). This decreasing trend of soil organic matter content in Bangladesh soil results in reduced soil fertility, and it has raised concerns towards the sustainability of agricultural production. Therefore, it is urgent to conserve and add nutrients to the soil through the balance application of compost and inorganic fertilizers, which can help to maintain and increase the nutrient reserves of the soil.

Solid waste is the most critical environmental problem in Bangladesh due to improper waste management system (Favoino \& Hogg, 2008). The weak waste management system is an alarming problem in Bangladesh, where around 50 percent of total waste is uncollected and stays in the environment as untreated (Hasan, 1998). Uncollected garbage goes untreated and resulting in water contamination, disease outbreak, and greenhouse gas emissions (Favoino \& Hogg, 2008). Untreated waste generates mostly methane, which is 25 times more potent than carbon dioxide, which is responsible for global warming (Crosson, 2008). To address this burning problem of decreasing soil organic matter content and declining soil fertility status, composting of these solid wastes may play an important role in waste management to keep the environment clean and achieve a sustainable agricultural system by improving soil health (Bari \& Koenig, 2002). Among the solid wastes, organic wastes such as kitchen, dairy, drainage, and garden wastes can be recycled through the process of composting. This compost can maintain soil health and improve soil fertility status, which is a prerequisite for achieving long term sustainable agricultural systems.

Sustainable agriculture is a way of raising food production that is healthy for men and animals, does not harm the environment, is humanitarian for workers, and provides a fair wage to the farmer. A common philosophy among sustainable agriculture practitioners is that "healthy" soil is a critical component of sustainability. This paper is an intensive effort to explore the current status of composting in Bangladesh.

\section{Current Scenario of Composting in Bangladesh}

The prime goal of composting in Bangladesh is to reduce and recycle solid waste into organic fertilizer, which can be used primarily as a soil conditioner. With the increase of population and urbanization, these wastes are generated from different sectors such as domestic, commercial, and industrial sectors (Shekdar, 2009). The amount of waste generation is much higher in metropolitan areas compared to small municipalities. In urban areas, around $0.47-0.5 \mathrm{~kg}$ of waste per person is generated every day. In contrast, this waste generation rate is almost half ( 0.25 to $0.3 \mathrm{~kg}$ per person/day) in small municipalities (Sujauddin, Huda, \& Hoque, 2008). Households and commercial sectors are the two primary sources of organic solid waste in Bangladesh. About $75 \%$ of the total solid come 
from households, and approximately $20 \%$ come from commercial areas (Guerrero, Maas, \& Hogland, 2013). Approximately 4.86 million tons of solid waste is produced in urban areas of Bangladesh each year, where organic fraction covers about 75\% - 85\% (Aminul, 2005).

Despite its potential reuse value, from this large volume, only $2 \%$ of the total organic wastes are recycled and composted to organic fertilizers (Kabir, 2015). Most of the composting areas are very small (one to five-ton capacity per day), and these are designed to demonstrate composting as an option for SWM (solid waste management) only, not for commercial purposes (Matter, Ahsan, Marbach, \& Zurbrugg, 2015). Therefore, there is a big scope to collect and recycle organic waste for composting for commercial purposes, which can serve as a core foundation of a sustainable agricultural production system. However, the sustainability and scalability of the composting plants are not satisfactory in Bangladesh. The main reason is the variety of different organizations and individually run composting processes without proper training and technologies. Adequate training on the selection of composting materials, overall composting process, packing, storage, and marketing are not available among the individual community people and establish composting organizations in Bangladesh.

\subsection{Composting Materials}

The selection of the most appropriate raw material is an essential component for preparing quality compost (Fourti, Jedidi, \& Hassen, 2010). The good composting materials should have a higher $\mathrm{C}: \mathrm{N}$ ratio, which facilitates the composting process. The composting process occurs effectively when the C:N ratio lies between 10:1 and 20:1 (Huang, Wong, Wu, \& Nagar, 2004). The speed of the composting process becomes rapid when the $\mathrm{C}: \mathrm{N}$ ratio of the composting materials remains 30:1 or less (Gajalakshmi \& Abbasi, 2008). Carbon-rich solid waste materials help to make the compost light and provide a fluffy body, and nitrogen or protein-rich waste materials provide raw materials for making enzymes (Hubbe, Nazhad, \& Sanchez, 2010). Table 1 comprises the possible waste materials that can be used in compost piles.

A healthy compost pile should have much more carbon than nitrogen (Bernal, Alburquerque, \& Moral, 2009). A simple rule of thumb is to use one-third green and two-thirds brown materials. The bulkiness of the brown materials allows oxygen to penetrate and nourish the organisms that reside there. Too much nitrogen makes for a dense, smelly, slowly decomposing anaerobic mass (Pan, Dam, \& Sen, 2011). Good composting hygiene means covering fresh nitrogen-rich material, which can release odors if exposed to open air, with carbon-rich material, which often exudes a fresh, wonderful smell (Debertoldi, Vallini, \& Pera, 1983).

\subsection{Compost Industries}

The extent of compost availability is limited in the market of Bangladesh because 
Table 1. List of composting materials with their respective prospects to use as a composting material [Adopted from (Longview, 2020)].

\begin{tabular}{|c|c|c|}
\hline Materials & Carbon/Nitrogen & Information \\
\hline Wood ash & Carbon & $\begin{array}{l}\text { Only use ash from clean materials; } \\
\text { sprinkle lightly }\end{array}$ \\
\hline Tea leaves & Nitrogen & Loose or in bags \\
\hline Table scraps & Nitrogen & Add with dry carbon items \\
\hline Sawdust pellets & Carbon & $\begin{array}{l}\text { High carbon levels; add in layers to avoid } \\
\text { clumping }\end{array}$ \\
\hline Newspaper & Carbon & Avoid using glossy paper and colored inks \\
\hline Leaves & Carbon & Leaves break down faster when shredded \\
\hline Lawn \& garden weeds & Nitrogen & Only use weeds which have not gone to seed \\
\hline Green comfrey leaves & Nitrogen & Excellent compost "activator" \\
\hline Grass clippings & Nitrogen & $\begin{array}{l}\text { Add in thin layers so they don't mat } \\
\text { into clumps }\end{array}$ \\
\hline Fruit and vegetable scraps & Nitrogen & Add with dry carbon items \\
\hline Flowers, cuttings & Nitrogen & Chop up any long woody stems \\
\hline Eggshells & Neutral & Best when crushed \\
\hline Corn cobs, stalks & Carbon & Slow to decompose; best if chopped up \\
\hline Chicken manure & Nitrogen & Excellent compost "activator" \\
\hline
\end{tabular}

of the minimal number of authorized commercial composting industries (Kabir, 2015; Matter et al., 2015). The development history of composting sectors is very recent in Bangladesh. Waste Concern, a local non-government organization in Bangladesh, firstly started the community based composting project in Dhaka (Halder et al., 2014). This NGO started its journey in 1995, but they initiated the composting project in the year of 2001. Initially, Waste Concern worked within a close partnership with the government, private organizations, and local community members to improve solid waste management in Dhaka city. After that, they started this composting project in Khulna in partnership with PRISM (a non-profit voluntary organization) Bangladesh. Through the United Nations Children's Fund (UNICEF), 10 composting plants were constructed in 14 municipalities throughout the country (Zurbrugg, 2002). It has over 20 members now and has attracted international funding from organizations including, UNDP (United Nation Development Programme) and USAID (United States Agency for International Development) (Cofie, Rao, Fernando, \& Johannes, 2014). The research and extension institutions like Bangladesh Agricultural University (BAU), Bangladesh Agricultural Research Institute (BARI), are bridging the farmers' access to the most appropriate and cost-effective composting technologies.

Other than Waste Concern, different organizations are coming forward in solid waste management through advanced composting technologies such as Annapurna Agro Service, Grameen Shakti, and Rural Development Academy (RDA). 
Other development facilitators (e.g. Katalyst, Innovision Consulting Pvt. Ltd., donor agencies, etc.) and enterprises (e.g. Rash Agro Enterprise, Achme Laboratories, etc.) have come forward to work for the promotion and availability of compost in Bangladesh (Cofie et al., 2014). Recently, many small farmers are preparing compost at the household level after getting proper training from the government with the help of the active collaboration of private organizations. But the main problem is the small capacity ( 1 - 5 ton per day) of these composting industries that are located either in the community area or in the dumping site of the municipalities (Aminul, 2005; Yousuf, 2005). Only two composting industries are running large-sized composting plants (130 ton per day), operated by World Wide Recycling (WWR) and Waste Concern in Dhaka (Zurbrügg, Drescher, Rytz, Sinha, \& Enayetullah, 2005). However, at present most of the plants have become redundant or have scaled-down operations because of a lack of compost marketing initiatives. Until 2008, only three to five composting industries had government certification. Currently, as per Bangladesh Fertilizer Association and Bangladesh Organic Products Manufacturer Association, 32 compost companies have government certification, and about 200 companies are in the queue (Cofie et al., 2014).

\section{Process of Compost Preparation}

The composting process is the combination of materials (manure, straw, green waste, etc.) that are then digested by naturally occurring microbes into a material that is available to plants for use as a nutrient source (Pan et al., 2011). The process relies on the right combination of carbon (wood, straw) and nitrogen (pig, poultry manure), the correct moisture content, and an ability to blend and aerate the materials. Composting organisms require four equally important ingredients to work effectively (Hubbe et al., 2010), and those are carbon, nitrogen, oxygen, and water. Carbon is required for energy; the microbial oxidation of carbon produces the heat if included at suggested levels. High carbon materials tend to be brown and dry. Nitrogen helps to grow and reproduce more organisms to oxidize the carbon. High nitrogen materials tend to be green (or colorful, such as fruits and vegetables) and wet. Oxygen is for oxidizing the carbon, the decomposition process. Water is required in the right amount to maintain microbial activities without causing the anaerobic condition (Cooperband, 2000; Mata-Alvarez, Macé, \& Llabrés, 2000). The method of composting followed in Bangladesh is presented in Figure 1.

The composting process involves three phases and uses diverse microflora such as bacteria, fungi, and mesophilic and thermophilic organisms (Büyüksönmez, Rynk, Hess, \& Bechinski, 2000), eventually converting organic waste to humus (Zeng, Singh, \& Chen, 2011). During the first phase, there is an increase in carbon dioxide along with the temperature. The substrate is reduced due to the degradation of sugar and proteins by the action of mesophilic organisms (Novinsak, Surette, Allain, \& Filion, 2008; Sundberg, Smars, \& Jonsson, 2004; Zeng et al., 2011). The second phase leads to an increase in the temperature in the compost 


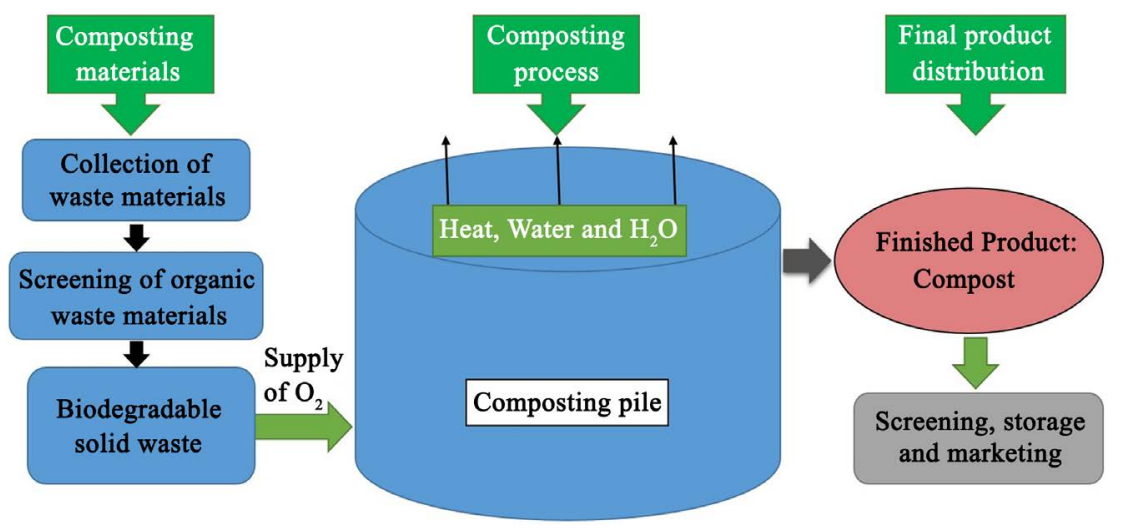

Figure 1. The process of composting followed in Bangladesh (Source: Author).

piles from $45^{\circ} \mathrm{C}$ to approximately $70^{\circ} \mathrm{C}$, and the mesophiles are replaced by thermophiles (Sundberg et al., 2004). Large numbers of pathogenic individuals are degraded during this time (Novinsak et al., 2008). The third phase begins with the decrease in temperature of the compost pile. Then the prepared composts are ready to be stored and marketing for final use in the field.

\section{Implication of Compost in Agriculture}

To feed the growing population in Bangladesh, intensive agricultural practices deteriorating the quality of soil and ultimately reduces the crop yield. Hence, an increased crop yields without compromising the soil health as the final consequence of compost application in soil. When the application of compost reduces the incidence of weeds, pests, and diseases, the use of herbicides and pesticides can be reduced or avoided. The avoided use can consequently be credited to the system as an environmental saving. Compost serves as a storehouse or reservoir of essential plant nutrients in the soil (Hendrix, Coleman, \& Crossley, 1992). As compost is derived from plants, they tend to contain many of the macro and micronutrients required for plant growth (Hargreaves, Adl, \& Warman, 2008). It also helps in carbon sequestration (Figure 2), and sequestration of $\mathrm{C}$ into the soil can be seen as the removal of $\mathrm{C}$ from the atmosphere and translated into saved $\mathrm{CO}_{2}$ emissions (Lal, 2008). The supply of nutrients with compost substitutes the use of mineral fertilizers.

Furthermore, compost is considered as a practical option for phosphorous recycling (Afroz, Hanaki, \& Hasegawa-Kurisu, 2009; Bernal et al., 2009; Cordell, White, Drangert, \& Neset, 2009; Shekdar, 2009), which is a growing issue as a consequence of the foreseen shortage of mineral $\mathrm{P}$ for agriculture fertilization. The application of compost could prevent soil erosion and thereby avoid losses of arable land. One potential benefit of compost is to increase the capacity of soil to retain water that can reduce the amount of irrigation water from surface and groundwater resources. Compost can improve soil health and increase the soil workability (Brown \& Cotton, 2011). Improved soil workability can potentially decrease energy requirements for agricultural operations. Changes in soil biodiversity after compost addition might influence either positively or negatively the 


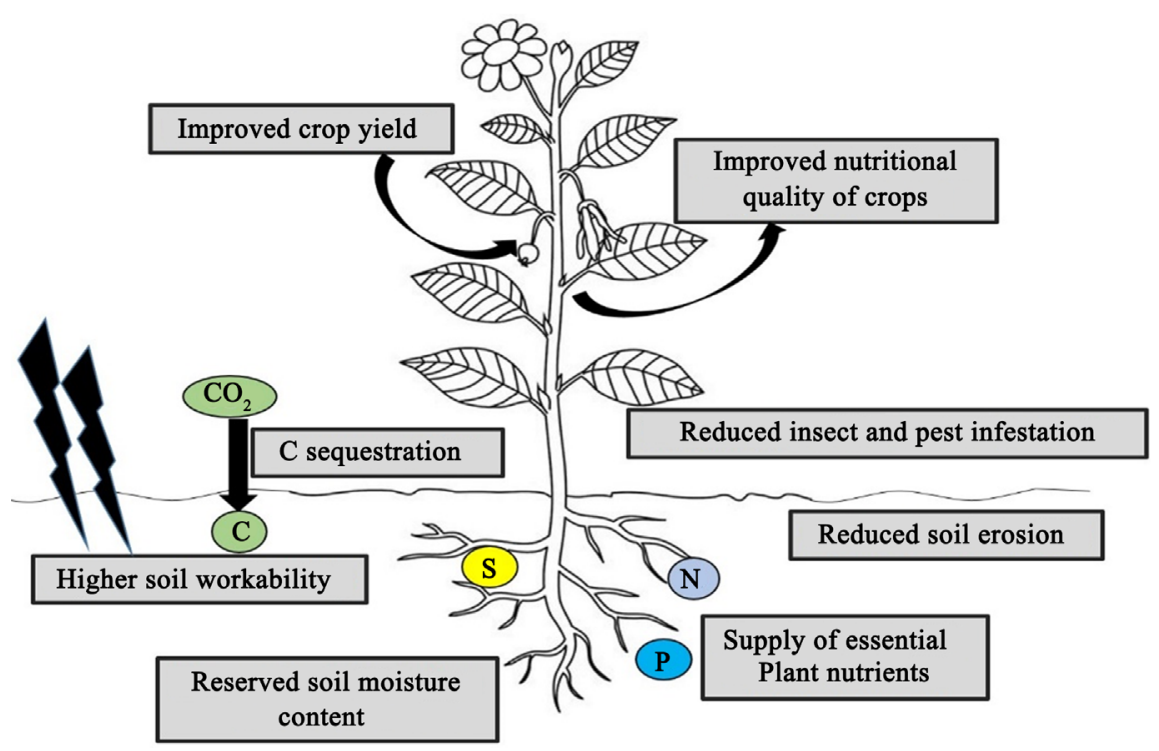

Figure 2. Benefits of using compost in agriculture (Source: Author).

services delivered by the ecosystem. But, mostly the altered soil biodiversity due to compost application in soil positively related to improved soil health and crop yield (Nair \& Ngouajio, 2012).

\section{Benefits and Constraints of Using Compost}

Compost acts as a soil conditioner by creating rich humus pole for crop production and supplies nutrients for plant growth as well as helps to retain soil moisture. The composting process can recycle around $30 \%$ of household waste; those can add organic matter to soils. Other than household wastes, it reduces landfill waste, and among the total landfill waste, around one-third is made up of compostable materials (Mata-Alvarez et al., 2000). Composting offers a natural alternative to chemical fertilizers, and the microorganisms in compost help to aerate the soil for maintaining a healthy soil environment. The high organic carbon content and biological activity of compost make it practical for applications such as erosion control and revegetation (Anastasi, Varese, \& Filipello Marchisio, 2017). An outline of the literature review dealing with the several potential benefits (Figure 2) resulting from compost application.

On the other hand, the composting process creates harmful methane gas (Hao, Chang, Larney, \& Travis, 2001) as it breaks down, increasing the rate of global warming and climate change (Dlugokencky, Nisbet, Fisher, \& Lowry, 2011). The application of compost may also result in environmental and agronomic drawbacks, such as gaseous and leachate emissions, and an increase in salt and heavy metal content, etc. (Favoino \& Hogg, 2008; Hargreaves et al., 2008). Agricultural users might have concerns regarding possible levels of heavy metals and other possible contaminants in compost, mainly mixed municipal solid wastes. The potential for contamination becomes an important issue when compost is used on food crops (Eghball et al., 1997; Pinamonti, Stringari, Gasperi, \& Zorzi, 
1997). Besides, the nutrient value of compost is low compared with that of chemical fertilizers, and the rate of nutrient release is slow so that it cannot usually meet the nutrient requirement of crops in a short time, thus resulting in some nutrient deficiency. Compost is beneficial for soil, environment and economic aspects with almost no negative attributes (Table 2).

\section{Opportunities and Challenges of the Composting Sector in Bangladesh}

The waste generation rate is very high in an overpopulated country like Bangladesh, while the scope or opportunities of composting is very high (Table 3 ). To produce quality compost, the Bangladesh government enacted compost standards and regulations in 2008, having the authority to certify and register commercial composting industries. Followed by the regulatory rules, the government also approved the 3R (Reduce, Reuse, and Recycle) strategy in 2010 with the instruction to community people to dispose of their waste separately based on their biodegradability. Integrated nutrient management or balanced fertilization needs to be promoted to maintain sustainable agriculture in Bangladesh, which can be achieved by using compost as organic fertilizer. This strategy will contribute to an increase in agricultural production and safeguard the environment. Recently, the government is providing technical and financial support to farmers

Table 2. Benefits of using compost in the aspect of soil, environment, and econometric.

\begin{tabular}{|c|c|}
\hline Areas of Benefit & Benefits of using compost \\
\hline \multirow{9}{*}{$\begin{array}{l}\text { Soil health } \\
\text { aspects }\end{array}$} & 1) It improves soil structure, which helps plant root growth. \\
\hline & 2) Higher activity of soil microbes helps to increase soil fertility \\
\hline & and biological activity, which ultimately leads to a sufficient supply \\
\hline & of essential plant nutrients. \\
\hline & 3) Compost helps to increase the cation exchange capacity (CEC) \\
\hline & of soil and contributes to soil organic matter build-up. \\
\hline & 4) It reduces soil erosion and improves water holding capacity of the soil. \\
\hline & It replenishes exhausted farm soils by replacing trace minerals and \\
\hline & organic material. \\
\hline \multirow{6}{*}{$\begin{array}{l}\text { Environmental } \\
\text { aspects }\end{array}$} & $\begin{array}{l}\text { 1) Recycling of waste materials helps to keep the environment clean } \\
\text { from pollution. }\end{array}$ \\
\hline & 2) Compost helps to reduce GHG (e.g. carbon dioxide) emission from \\
\hline & the soil by recycling waste materials into fertilizers. \\
\hline & 3) Composting helps to minimize the pressure on chemical fertilizers, \\
\hline & which has a negative impact on soil, water, and environmental \\
\hline & quality through leaching and gas emission. \\
\hline \multirow{10}{*}{$\begin{array}{l}\text { Economical } \\
\text { aspects }\end{array}$} & 1) It reduces the cost of production by minimizing the use of fertilizers \\
\hline & in the long run. Whether the benefits are not visible instantly, it helps \\
\hline & to improve soil fertility and contributes to an increase in crop yield \\
\hline & in the long term. \\
\hline & 2) Contributes to the national economy by creating income-generating \\
\hline & sectors (composting industries) for the unemployed poor people. \\
\hline & 3) Increased water holding capacity of the soil decreases the frequency \\
\hline & of irrigation, which minimizes the cost of irrigation. \\
\hline & 4) Improves the health and workability of soils, resulting in \\
\hline & less fuel consumption in tillage operation. \\
\hline
\end{tabular}


Table 3. Status of composting in Bangladesh regarding the opportunities and challenges to overcome summarized from different research findings.

\begin{tabular}{|c|c|}
\hline Status of Composting in Bangladesh & References \\
\hline \multicolumn{2}{|l|}{ Opportunities } \\
\hline 1) Rate of waste generation per day is very high & Kabir (2015) \\
\hline 2) Most of the household wastes are organic, and those & Alamgir and Ahsan (2007); \\
\hline are biodegradable & Sujauddin et al. (2008); Aminul (2005) \\
\hline 3) A positive attitude from the Government & Afroz et al. (2009) \\
\hline 4) Good source of organic fertilizers & Svensson, Odlare, and Pell (2004) \\
\hline 5) Improves soil health and sustainable agriculture & Hargreaves et al. (2008) \\
\hline \multicolumn{2}{|l|}{ Challenges } \\
\hline 1) Poor waste segregation in source & Matter, Dietschi, and Zurbrugg (2013) \\
\hline 2) Quality compost preparation with minimum & Gabhane et al. (2012); \\
\hline contaminants & Martínez-Blanco et al. (2013) \\
\hline 3) Lack of knowledge on the benefits of using compost & Guerrero et al. (2013) \\
\hline 4) Weak regulatory enforcement systems & Dhokhikah and Trihadiningrum (2012) \\
\hline 5) The negative attitude of community people & Yousuf (2005) \\
\hline
\end{tabular}

to practice the composting process and use it as fertilizer. Co-marketing of compost with chemical fertilizers also represents an opportunity. The government of Bangladesh has exempted value-added tax (VAT) and sales tax from composts as well as reduced the import duties on environmentally friendly technologies to promote organic waste recycling. The environment department has started issuing environmental clearance certificates for composting plants. They are promoting source segregation by implementing a $3 \mathrm{R}$ pilot project in major cities of Bangladesh by providing three types of bins. The Department of Environment has also taken up composting projects for 64 districts, and three municipalities have already established composting facilities. The project is financed by the Climate Change Trust Fund of the Government of Bangladesh.

Challenges Composting in Bangladesh is confronted with several obstacles that threaten the development of the sector (Table 3). Inadequate source segregation and waste collection is a primary constraint to the industry due to lack of knowledge on the importance of source segregation and of recycling organic waste. Farmers don't have proper experience of the benefits of using compost. Compost often has a negative connotation due to the types of input materials used, such as MSW, and this problem can be managed by waste source segregation. Farmers are often neutral to use compost because of long-distance composting plants and application site, which involved higher cost in transportation. Inappropriate policies such as chemical fertilizers are sold at subsidized prices, which distorts the market for compost. Municipalities do not prioritize in composting and do not have enough capacity to operate and maintain composting plants and marketing policies. Due to inadequate land for organic waste recycling and local resistance to set up composting facilities within the community, the process of waste management is getting complex. Weak regulatory enforcement systems with poor monitoring capabilities fail to ensure proper waste management systems and standards. The current compost certification process 


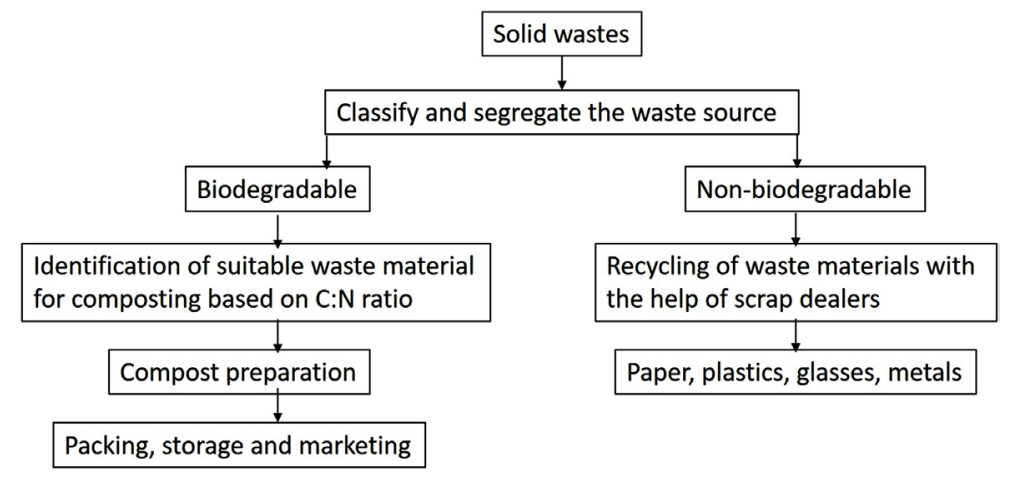

Figure 3. The legal framework of composting in Bangladesh (Source: Author).

is complicated and time-consuming (one to two years to obtain the permit to market the compost), which discourages the compost producers. However, the composting industries are following a legal framework as instructed by the government to produce quality compost commercially (Figure 3 ). The management of solid wastes for composting covers the full cycle from waste generation, collection, recycling or composting, marketing, and use is field level (Figure 3). The legal framework of composting is represented below.

\section{Conclusion}

Composting through appropriate technology in combination with the sound financial management system and a proper marketing system ensures quality compost production. The high cost of land and lack of an appropriate system of management are the main constraints in composting found in different kinds of literature. In the context of Bangladesh, inappropriate waste management systems and lack of government and community support make the composting process difficult. But, now, various non-government organizations are trying to accelerate the process of composting by providing financial support as well as building awareness among the community people. The use of compost on land can have beneficial effects on the plant-soil system, environmental and economic aspects, which motivates people in composting. An inappropriate waste management system in Bangladesh increases the risk of heavy metal toxicity in the compost. If that compost is used in the agricultural field, those heavy metals can enter the human food cycle by consuming food. Therefore, a proper waste management system should be installed to get quality compost. Future work should be focused on finding more suitable compost production techniques with the sound financial management system and building awareness among the people regarding the importance of waste management and composting process.

\section{Acknowledgements}

The authors would like to acknowledge the facilities of the Department of Soil Science, Bangladesh Agricultural University, for providing logistic support to conduct this desktop research. 


\section{Availability of Data and Materials}

This is desktop research conducted in the Department of Soil Science, BAU. All the data and information were gathered from published research work on composting available online.

\section{Funding}

There was no funding organization to support this study. This desktop research was conducted comprising available data and information in the field of composting research.

\section{Authors' Contribution}

MMS and MGK contributed equally to this review by writing the first draft of the manuscript. MAA and MJ provided structured guidelines during the preparation of the manuscript. All authors contributed to the manuscript revision and editing and approved the submitted version of the manuscript.

\section{Conflicts of Interest}

Authors declare no financial and non-financial competing interest in this review.

\section{References}

Afroz, R., Hanaki, K., \& Hasegawa-Kurisu, K. (2009). Willingness to Pay for Waste Management Improvement in Dhaka City, Bangladesh. Journal of Environmental Management, 90, 492-503. https://doi.org/10.1016/j.jenvman.2007.12.012

Alamgir, M., \& Ahsan, A. (2007). Municipal Solid Waste and Recovery Potential: Bangladesh Prospective. Iranian Journal of Environmental Health, Science and Engineering, 4, 67-76.

Aminul, A. (2005). Generation, Composition and Characteristics of Municipal Solid Wastes in Some Major Cities of Bangladesh. Master of Science in Civil Engineering, Khulna: Khulna University of Engineering \& Technology (KUET).

Anastasi, A., Varese, G. C., \& Filipello Marchisio, V. (2017). Isolation and Identification of Fungal Communities in Compost and Vermicompost. Mycologia, 97, 33-44. https://doi.org/10.3852/mycologia.97.1.33

BARC (1999). Land Degradation Situation in Bangladesh. Dhaka: Farmgate.

Bari, Q. H., \& Koenig, A. (2002). Measuring Solid Waste Compost Maturity: A Review and Practice. Bangladesh Environment, 2, 7-12.

Bernal, M. P., Alburquerque, J. A., \& Moral, R. (2009). Composting of Animal Manures and Chemical Criteria for Compost Maturity Assessment. A Review. Bioresource Technology, 100, 5444-5453. https://doi.org/10.1016/j.biortech.2008.11.027

Bhuiya, Z. H. (1987). Organic Matter Status and Organic Recycling in Bangladesh Soils. Resources and Conservation, 13, 117-124. https://doi.org/10.1016/0166-3097(87)90055-1

Brown, S., \& Cotton, M. (2011). Changes in Soil Properties and Carbon Content Following Compost Application: Results of On-Farm Sampling. Compost Science \& Utilization, 19, 87-96. https://doi.org/10.1080/1065657X.2011.10736983

Büyüksönmez, F., Rynk, R., Hess, T. F., \& Bechinski, E. (2000). Literature Review: Occur- 
rence, Degradation and Fate of Pesticides During Composting: Part II: Occurrence and Fate of Pesticides in Compost and Composting Systems. Compost Science \& Utilization, 8, 61-81. https://doi.org/10.1080/1065657X.2000.10701751

Cofie, O., Rao, K. C., Fernando, S., \& Johannes, P. (2014). Composting Experience in Developing Countries: Drivers and Constraints for Composting Development in Ghana, India, Bangladesh and Sri Lanka.

Cooperband, L. R. (2000). Composting: Art and Science of Organic Waste Conversion to a Valuable Soil Resource. Laboratory Medicine, 31, 283-290. https://doi.org/10.1309/W286-LQF1-R2M2-1WNT

Cordell, D., White, S., Drangert, J. O., \& Neset, T. S. S. (2009). Preferred Future Phosphorus Scenarios: A Framework for Meeting Long-Term Phosphorus Needs for Global Food Demand. In the International Conference on Nutrient Recovery from Wastewater Streams (pp. 23-43). London, United Kingdom: IWA Publishing.

Crosson, E. R. (2008). A Cavity Ring-Down Analyzer for Measuring Atmospheric Levels of Methane, Carbon Dioxide, and Water Vapor. Applied Physics B, 92, 403-408. https://doi.org/10.1007/s00340-008-3135-y

Debertoldi, M., Vallini, G., \& Pera, A. (1983). The Biology of Composting: A Review. Waste Management \& Research, 1, 157-176. https://doi.org/10.1016/0734-242X(83)90055-1

Dhokhikah, Y., \& Trihadiningrum, Y. (2012). Solid Waste Management in Asian Developing Countries: Challenges and Opportunities. Journal of Applied Environmental and Biological Sciences, 2, 329-335.

Dlugokencky, E. J., Nisbet, E. G., Fisher, R., \& Lowry, D. (2011). Global Atmospheric Methane: Budget, Changes and Dangers. Philosophical Transactions of the Royal Society A Mathematical Physical and Engineering Sciences, 369, 2058-2072. https://doi.org/10.1098/rsta.2010.0341

Eghball, B., Power, J. F., Gilley, J. E., \& Doran, J. W. (1997). Nutrient, Carbon, and Mass Loss during Composting of Beef Cattle Feedlot Manure. Journal of Environment Quality, 26, 189-193. https://doi.org/10.2134/jeq1997.00472425002600010027x

Favoino, E., \& Hogg, D. (2008). The Potential Role of Compost in Reducing Greenhouse Gases. Waste Management \& Research, 26, 61-69. https://doi.org/10.1177/0734242X08088584

Fourti, O., Jedidi, N., \& Hassen, A. (2010). Humic Substances Change during the CoComposting Process of Municipal Solid Wastes and Sewage Sludge. World Journal of Microbiology and Biotechnology, 26, 2117-2122. https://doi.org/10.1007/s11274-010-0411-x

Gabhane, J., William, S. P., Bidyadhar, R., Bhilawe, P., Anand, D., Vaidya, A. N., \& Wate, S. R. (2012). Additives Aided Composting of Green Waste: Effects on Organic Matter Degradation, Compost Maturity, and Quality of the Finished Compost. Bioresource Technology, 114, 382-388. https://doi.org/10.1016/j.biortech.2012.02.040

Gajalakshmi, S., \& Abbasi, S. A. (2008). Solid Waste Management by Composting: State of the Art. Critical Reviews in Environmental Science and Technology, 38, 311-400. https://doi.org/10.1080/10643380701413633

Guerrero, L. A., Maas, G., \& Hogland, W. (2013). Solid Waste Management Challenges for Cities in Developing Countries. Waste Management, 33, 220-232. https://doi.org/10.1016/j.wasman.2012.09.008

Halder, P. K., Paul, N., Hoque, M. E., Hoque, A. S. M., Parvez, M. S., Rahman, M. H., \& Ali, M. (2014). Municipal Solid Waste and Its Management in Rajshahi City, Bangladesh: A Source of Energy. International Journal of Renewable Energy Research, 4, 
168-175.

Hao, X., Chang, C., Larney, F. J., \& Travis, G. R. (2001). Greenhouse Gas Emissions during Cattle Feedlot Manure Composting. Journal of Environment Quality, 30, 376-386. https://doi.org/10.2134/jeq2001.302376x

Hargreaves, J., Adl, M., \& Warman, P. (2008). A Review of the Use of Composted Municipal Solid Waste in Agriculture. Agriculture, Ecosystems \& Environment, 123, 1-14. https://doi.org/10.1016/j.agee.2007.07.004

Hasan, S. (1998). Problems of Municipal Waste Management in Bangladesh: An Inquiry into Its Nature. Habitat International, 22, 191-202. https://doi.org/10.1016/S0197-3975(97)00039-8

Hendrix, P. F., Coleman, D. C., \& Crossley, D. A. (1992). Using Knowledge of Soil Nutrient Cycling Processes to Design Sustainable Agriculture. Journal of Sustainable Agriculture, 2, 63-82. https://doi.org/10.1300/J064v02n03_06

Huang, G. F., Wong, J. W., Wu, Q. T., \& Nagar, B. B. (2004). Effect of C/N on Composting of Pig Manure with Sawdust. Waste Management, 24, 805-813. https://doi.org/10.1016/j.wasman.2004.03.011

Hubbe, M. A., Nazhad, M., \& Sanchez, C. (2010). Composting as a Way to Convert Cellulosic Biomass and Organic Waste into High-Value Soil Amendments: A Review. Bioresources, 5, 2808-2854. https://doi.org/10.15376/biores.5.4.2808-2854

Kabir, M. R. (2015). Municipal Solid Waste Management System: A Study on Dhaka North and South City Corporations. Journal of Bangladesh Institute of Planners, 8 , 35-48.

Lal, R. (2008). Soils and Sustainable Agriculture. A Review. Agronomy for Sustainable Development, 28, 57-64. https://doi.org/10.1051/agro:2007025

Longview (2020). Composting at Home. https://longviewtexas.gov/2537/Composting-at-Home

Martínez-Blanco, J., Lazcano, C., Christensen, T. H., Muñoz, P., Rieradevall, J., Møller, J., Boldrin, A. et al. (2013). Compost Benefits for Agriculture Evaluated by Life Cycle Assessment. A Review. Agronomy for Sustainable Development, 33, 721-732. https://doi.org/10.1007/s13593-013-0148-7

Mata-Alvarez, J., Macé, S., \& Llabrés, P. (2000). Anaerobic Digestion of Organic Solid Wastes. An Overview of Research Achievements and Perspectives. Bioresource Technology, 74, 3-16. https://doi.org/10.1016/S0960-8524(00)00023-7

Matter, A., Ahsan, M., Marbach, M., \& Zurbrugg, C. (2015). Impacts of Policy and Market Incentives for Solid Waste Recycling in Dhaka, Bangladesh. Waste Management, 39, 321-328. https://doi.org/10.1016/j.wasman.2015.01.032

Matter, A., Dietschi, M., \& Zurbrugg, C. (2013). Improving the Informal Recycling Sector through Segregation of Waste in the Household-The Case of Dhaka Bangladesh. Habitat International, 38, 150-156. https://doi.org/10.1016/j.habitatint.2012.06.001

Nair, A., \& Ngouajio, M. (2012). Soil Microbial Biomass, Functional Microbial Diversity, and Nematode Community Structure as Affected by Cover Crops and Compost in an Organic Vegetable Production System. Applied Soil Ecology, 58, 45-55. https://doi.org/10.1016/j.apsoil.2012.03.008

Novinsak, A., Surette, C., Allain, C., \& Filion, M. (2008). Application of Molecular Technologies to Monitor the Microbial Content of Biosolids and Composted Biosolids. Water Science and Technology, 57, 471-477. https://doi.org/10.2166/wst.2008.019

Noyd, R. K., Pfleger, F. L., \& Norland, M. R. (1996). Field Responses to Added Organic Matter, Arbuscular Mycorrhizal Fungi, and Fertilizer in Reclamation of Taconite Iron 
Ore Tailing. Plant and Soil, 179, 89-97. https://doi.org/10.1007/BF00011646

Pan, I., Dam, B., \& Sen, S. K. (2011). Composting of Common Organic Wastes Using Microbial Inoculants. 3 Biotech, 2, 127-134. https://doi.org/10.1007/s13205-011-0033-5

Pinamonti, F., Stringari, G., Gasperi, F., \& Zorzi, G. (1997). The Use of Compost: Its Effects on Heavy Metal Levels in Soil and Plants. Resources, Conservation and Recycling, 21, 129-143. https://doi.org/10.1016/S0921-3449(97)00032-3

Senesi, N. (1989). Composted Materials as Organic Fertilizers. Science of the Total Environment, 81-82, 521-542. https://doi.org/10.1016/0048-9697(89)90161-7

Shekdar, A. V. (2009). Sustainable Solid Waste Management: An Integrated Approach for Asian Countries. Waste Management, 29, 1438-1448. https://doi.org/10.1016/j.wasman.2008.08.025

Sujauddin, M., Huda, S. M., \& Hoque, A. T. (2008). Household Solid Waste Characteristics and Management in Chittagong, Bangladesh. Waste Management, 28, 1688-1695. https://doi.org/10.1016/j.wasman.2007.06.013

Sundberg, C., Smars, S., \& Jonsson, H. (2004). Low pH as an Inhibiting Factor in the Transition from Mesophilic to Thermophilic Phase in Composting. Bioresource Technology, 95, 145-150. https://doi.org/10.1016/j.biortech.2004.01.016

Svensson, K., Odlare, M., \& Pell, M. (2004). The Fertilizing Effect of Compost and Biogas Residues from Source Separated Household Waste. The Journal of Agricultural Science, 142, 461-467. https://doi.org/10.1017/S0021859604004514

Yousuf, T. (2005). Sustainability and Replication of Community-Based Composting: A Case Study of Bangladesh. Ph.D., Leicestershire: Loughborough University.

Zeng, J., Singh, D., \& Chen, S. (2011). Thermal Decomposition Kinetics of Wheat Straw Treated by Phanerochaete chrysosporium. International Biodeterioration \& Biodegradation, 65, 410-414. https://doi.org/10.1016/j.ibiod.2011.01.004

Zurbrugg, C. (2002). Urban Solid Waste Management in Low-Income Countries of Asia How to Cope with the Garbage Crisis.

Zurbrügg, C., Drescher, S., Rytz, I., Sinha, A. H. M. M., \& Enayetullah, I. (2005). Decentralised Composting in Bangladesh, a Win-Win Situation for All Stakeholders. Resources, Conservation and Recycling, 43, 281-292.

https://doi.org/10.1016/j.resconrec.2004.06.005 